ORNL/TM-1999/155

\title{
Assessment of Cost Savings of DOE's Return-on-Investment Program
}

Katherine L. Yuracko

Bruce Tonn

Mike Morris 
This report has been reproduced from the best available copy.

Reports are available to the public from the following source.

National Technical Information Service

5285 Port Royal Road

Springfield, VA 22161

Telephone: 703-605-6000 (1-800-553-6847)

TDD: $703-487-4639$

Fax: 703-605-6900

E-mail: orders@ntis.fedworld.gov

Web site: http://www.ntis.gov/ordering.htm

Reports are available to U.S. Department of Energy (DOE) employees, DOE contractors, Energy Technology Data Exchange (ETDE) representatives, and International Nuclear Information System (INIS) representatives from the following source.

Office of Scientific and Technical Information

P.O. Box 62

Oak Ridge, TN 37831

Telephone: $423-576-8401$

Fax: 423-576-5728

E-mail: reports@adonis.osti.gov

Web site: http://www.osti.gov/products/sources.html

Reports produced after January 1,1996, are generally available via the DOE Information Bridge (http://www.doe.gov/bridge).

This report was prepared as an account of work sponsored by an agency of the United States Government. Neither the United States Government nor any agency thereof, nor any of their employees, makes any warranty, express or implied, or assumes any legal liability or responsibility for the accuracy, completeness, or usefulness of any information, apparatus, product, or process disclosed, or represents that its use would not infringe privately owned rights. Reference herein to any specific commercial product, process, or service by trade name, trademark, manufacturer, or otherwise, does not necessarily constitute or imply its endorsement, recommendation, or favoring by the United States Government or any agency thereof. The views and opinions of authors expressed herein do not necessarily state or reflect those of the United States Government or any agency thereof. 


\title{
Assessment of Cost Savings of DOE's Return-on-Investment Program
}

\author{
Katherine L. Yuracko \\ Bruce Tonn \\ Mike Morris
}

August 1999

Prepared for the U.S. Department of Energy Office of Environmental Management Office of Pollution Prevention

Prepared by the Center for Life Cycle Analysis Oak Ridge National Laboratory Oak Ridge, Tennessee 37831 managed by

Lockheed Martin Energy Research Corporation for the U.S. Department of Energy under contract DE-AC05-96OR22464 


\section{Contents}

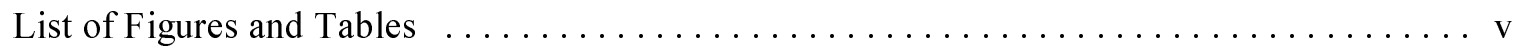

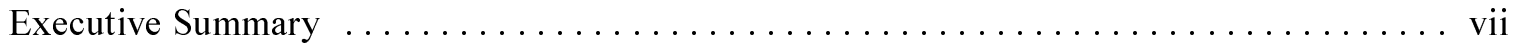

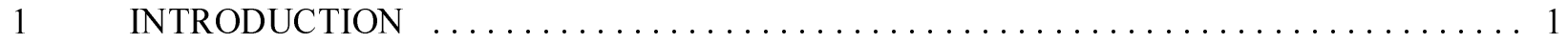

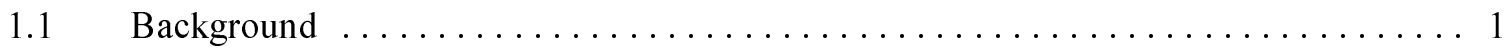

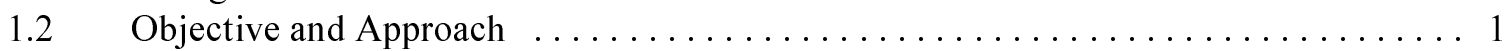

2 P2 PROJECT EVALUATION METHOD $\ldots \ldots \ldots \ldots \ldots \ldots \ldots \ldots \ldots \ldots \ldots \ldots$

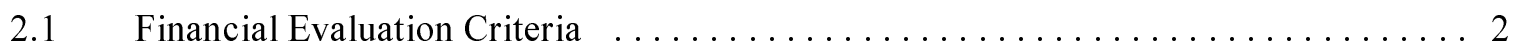

$2.2 \quad$ Non-Monetary Evaluation Criteria $\ldots \ldots \ldots \ldots \ldots \ldots \ldots \ldots \ldots \ldots \ldots \ldots \ldots \ldots$

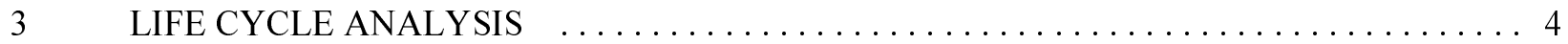

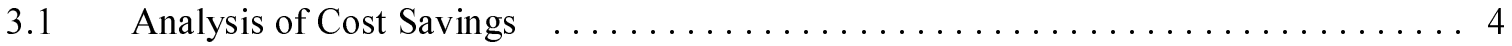

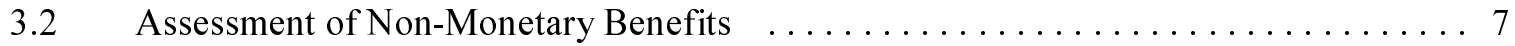

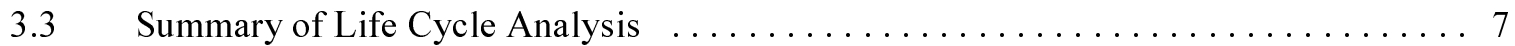

4 ASSESSMENT OF MANAGEMENT PROCESS $\ldots \ldots \ldots \ldots \ldots \ldots \ldots \ldots \ldots \ldots$

Attachment 1. The Sixteen P2 Projects Selected for Assessment $\ldots \ldots \ldots \ldots \ldots \ldots \ldots \ldots 15$

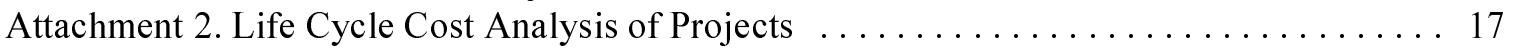

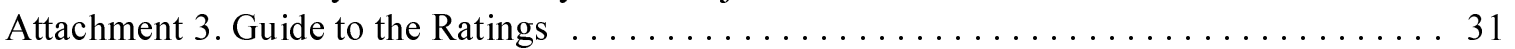




\section{Figures and Tables}

\section{Figures}

$1 \quad$ Most of the cost savings occur as avoided waste management costs $\ldots \ldots \ldots \ldots \ldots \ldots$

2 Richland's ROI management process $\ldots \ldots \ldots \ldots \ldots \ldots \ldots \ldots \ldots \ldots \ldots \ldots \ldots \ldots$

3 Success factors for a successful DOE pollution prevention ROI program $\ldots \ldots \ldots \ldots \ldots 10$

\section{Tables}

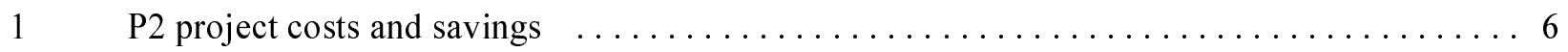

2 Reduced waste generation resulting from $13 \mathrm{P} 2$ projects $\ldots \ldots \ldots \ldots \ldots \ldots \ldots \ldots \ldots$

3 Assessment of non-monetary benefits of $\mathrm{P} 2$ projects $\ldots \ldots \ldots \ldots \ldots \ldots \ldots \ldots \ldots$

4 Life cycle analysis reveals that P2 projects produce significant financial and non-

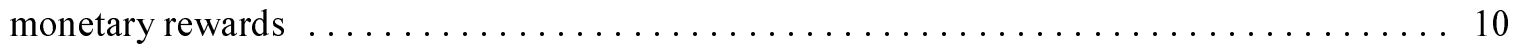




\section{Executive Summary}

The U.S. Department of Energy (DOE) Office of Pollution Prevention (EM-77) created a successful internally competed program to fund innovative projects based on projected returns. This is called the Return-on-Investment (ROI) program. EM-77 conducted a successful ROI pilot, developed and implemented sound management practices, and successfully transferred the program to several Operations Offices. Over the past 4 years sites have completed 262 ROI projects (costing $\$ 18.8$ million) with claimed first-year savings of $\$ 88$ million and claimed life cycle savings exceeding $\$ 300$ million. EM-77 requested that Oak Ridge National Laboratory perform an independent evaluation of the site-led, DOE-HQ-funded pollution prevention (P2) ROI program to assist the Department in determining whether claimed savings are real.

The approach for conducting this evaluation was to analyze a sample of $\mathrm{P} 2$ projects to identify actual project cost savings and other actual benefits - e.g., amount of waste avoided. To determine the projects for review, EM-77 provided a list of EM-funded projects at two Operations Offices: Oak Ridge and Richland. Sixteen projects (eight from each Operations Office) were selected at random from this list for review. Project documentation was requested from the sites, and this was followed by face-to-face interviews with project personnel. Of the 16 projects selected at random, two are still awaiting implementation, and no project interview was conducted for one project. Because the purpose of this study was to review projects after they have been implemented, the two uncompleted projects were eliminated from further consideration. The remainder of this report addresses the 13 completed projects for which we received documentation and performed interviews with project personnel. Both Oak Ridge and Richland staff pointed out that because of the selection approach used, this study did not review the most successful projects at their sites.

\section{$P 2$ projects perform better than expected. For}

8 of the 11 projects that estimated the ROI in the project proposal, the ROI as determined through our interviews exceeded the ROI in the project proposal. In some cases, the improvement was due to increased throughput (e.g.,analyzing more samples than anticipated) or finding additional uses for the new equipment. In other cases, the P2 projects had understated their financial benefits because project managers neglected benefits accruing to other organizations.
P2 projects produce significant cost savings

Average ROI from project proposal $\quad 558 \%$

Average actual ROI $611 \%$

Number of projects reviewed

Total implementation cost 13

Total life cycle savings
$\$ 606,000$

$\$ 30,000,000$

P2 projects yield high returns. The $13 \mathrm{P} 2$ projects saved 50 times the initial $\mathrm{P} 2$ investment. The implementation cost of $\$ 606,000$ for the 13 projects will result in life cycle savings of $\$ 30$ million. Only one of the projects did not realize any cost savings. In addition to significant cost savings, DOE realized environmental, health and safety, and programmatic benefits from the projects (e.g., eliminating 260,000 gallons per year of mixed low-level waste, reducing release of tritium into groundwater, reducing exposure to toxic materials, and making it possible to meet Tri-Party Agreement milestones). The analysis is summarized in Fig. ES-1 and Table ES-1. Cost estimates reported here reflect the total cost of each individual project over the total life of the project. However, they do not include what could prove to be a major benefit of the P2 program: sparing the Department the cost of building additional waste management facilities (e.g., additional disposal cells) in the future. Consequently, the true benefit of P2 investments may be even larger than reported here. 
Most cost savings are diffused across the DOE, not returned to the implementing project. As Fig. ES-1 shows, the majority of life cycle savings occur as avoided costs to DOE (primarily in the area of waste management), not as direct savings to the implementing project. Of the $\$ 30$ million life cycle savings, only $10 \%$ (\$3 million) represent direct savings to the implementing project. These savings are realized as labor savings (\$2.6 million) and avoided purchases $(\$ 419,000)$. The remainder of the savings - \$27 million - accrues to other projects; the implementing project does not reap these savings.

P2 cost savings are diffused between the implementing project and DOE Headquarters program offices (e.g., Office of Science, Office of Environmental Management, Office of Defense Programs), field offices, and different field organizations (e.g., EM-30, $40,50,60,70)$. For example, waste management costs are shared among the Office of Waste Management and multiple generator organizations. For the Oak Ridge projects reviewed, generators did not pay for disposal of their waste; therefore, they do not reap the benefits of waste reduction investments. Richland does have a charge-back system in place to charge generators for the operating (not fixed) costs of waste management facilities; however, charges apparently accrue to the larger generator organization and are not always assigned to individual project budgets. As a result, a project engineer would not reap the cost savings resulting from his waste reduction investments.

Of the 13 projects reviewed, one project accounted for $74 \%$ of the total savings. This $\mathrm{P} 2$ project modified an evaporator at a cost of $\$ 233,000$. This action eliminated generation of 370 cubic meters of liquid mixed low-level waste per year and resulted in life cycle savings from avoided waste management of $\$ 22$ million. Although the larger organization (the Tank Waste Remediation System) realized both the costs and benefits of the evaporator modification, the implementing project engineer saw only the cost and did not have access to funds within his project to pay that cost.

This example illustrates a key role of the ROI program: bridging the gap when the implementing project does not have access to funds to implement an action that will benefit the Department overall. The ROI program serves to bridge the gap any time there are stovepipes that cause one account to realize a cost and another account to reap the benefits. The most common example is a waste generator incurring the cost of waste reduction while the waste management organization realizes the savings; however, there are other instances as well.

Program Management. Both the Oak Ridge and the Richland Operations Offices have developed successful grassroots programs using streamlined processes which could serve as examples for the DOE complex. Dedicated teams administer the effort, champion the program, and assist generators in identifying P2 opportunities. 
Because financial investments and returns accrue to different entities, projects sometimes do not have sufficient incentive and/or access to funds to implement P2 opportunities if the funding must come from their direct program budgets. In addition, we were informed that lack of regulatory drivers and lack of management discretion contribute to managers' inability to make P2 investments from their project funds - and the consequent need for separate P2 funding. In Richland in particular, all discretionary funds are applied to meet regulatory requirements associated with the Tri-Party Agreement, leaving no funds available for worthwhile projects that lack regulatory drivers.
The ROI Program provides incentives to reap "hidden" benefits

Waste generators may have disincentives to incur the costs of P2 work when

- all or most of the savings accrue to a different organization,

- the savings are diffused among different offices and organizations,

- the benefits are related to health and safety, the environment, or programmatic costs.

By looking past stovepipes and focusing on the overall benefits to DOE, the ROI program encourages projects that are cost-effective from the standpoint of the Department.

Furthermore, non-monetary benefits of $\mathrm{P} 2$ projects, such as protection of natural resources, are typically not fully considered in decision-making. This, too, may contribute to an under-investment in P2 opportunities. This study found that $\mathrm{P} 2$ projects produce significant non-monetary benefits in addition to the documented financial rewards.

EM-77's ROI program serves a key role in optimizing the function of the system within these constraints to achieve the significant financial, health and safety, environmental, and programmatic benefits of P2 investments. For example, the ROI program looks past organizational "stovepipes" to fund projects that are cost-effective from the standpoint of DOE and taxpayers. It is recommended that DOE aggressively capture the documented benefits of pollution prevention by continuing to fund the ROI program. 
Table ES-1. Life cycle analysis reveals that $\mathrm{P} 2$ projects produce significant financial and non-monetary rewards

\begin{tabular}{|c|c|c|c|c|c|c|}
\hline Project Name & $\begin{array}{c}\text { mplementation } \\
\text { Cost } \\
(\$ 1000 \text { s })\end{array}$ & $\begin{array}{l}\text { Life Cycle } \\
\text { Savings } \\
\text { (\$1000s) }\end{array}$ & $\begin{array}{l}\text { Pollution/ } \\
\text { Waste } \\
\text { Prevented }\end{array}$ & $\begin{array}{l}\text { Environmental } \\
\text { Impacts }\end{array}$ & $\begin{array}{l}\text { Health } \\
\text { and } \\
\text { Safety }\end{array}$ & $\begin{array}{l}\text { Programmatic } \\
\text { Impacts }\end{array}$ \\
\hline $\begin{array}{l}\text { ORNL Cyanide by MIDI } \\
\text { Distillation Upgrade }\end{array}$ & 49 & 766 & & & & \\
\hline $\begin{array}{l}\text { ORNL Mercury Analyzer } \\
\text { Upgrade }\end{array}$ & 23 & 349 & & & & \\
\hline $\begin{array}{l}\text { ETTP Purchase Data } \\
\text { Security Degausser }\end{array}$ & 28 & 274 & & & & \\
\hline $\begin{array}{l}\text { ETTP Substitution of Poly Tanks } \\
\text { for Drums to Collect Acids }\end{array}$ & 21 & 105 & & & & \\
\hline $\begin{array}{l}\text { Y-12 Source Reduction of } \\
\text { Heavy Equipment Oils }\end{array}$ & 37 & $<0^{a}$ & & & & \\
\hline RL Basin Overflow Retention Tank & 13 & 1,450 & & & & \\
\hline $\begin{array}{l}\text { RL TWRS Evaporator } \\
\text { Modification }\end{array}$ & 233 & 22,300 & & & & \\
\hline RL Mixed Waste Rain Curtain & 149 & 791 & & & & \\
\hline RL Isolate Diversion Box & 18 & 3,410 & & & & \\
\hline $\begin{array}{l}\text { PNNL Microconcentric } \\
\text { Nebulizer }\end{array}$ & 2 & 3.0 & & & & \\
\hline $\begin{array}{l}\text { RL Eliminate Solid Waste Stream } \\
\text { with Treatment and Recycling }\end{array}$ & 5.6 & 296 & & & & \\
\hline RL In-Line Solvent Recovery & 22 & 49 & & & & \\
\hline $\begin{array}{l}\text { PNNL Metallography Photochemic } \\
\text { Reduction }\end{array}$ & ical & 249 & & & & \\
\hline \multicolumn{3}{|c|}{ Major improvement relative to baseline approach } & \multicolumn{4}{|c|}{ No change relative to baseline approach } \\
\hline
\end{tabular}

a Not quantified 


\section{INTRODUCTION}

\subsection{BACKGROUND}

In 1994-1995, the Pollution Prevention (P2) Executive Board of the U.S. Department of Energy (DOE) conducted a successful grassroots-style Return-on-Investment (ROI) pilot, based upon an effective industry program at Dow Chemical-Louisiana. This program was then implemented by five Operations Offices - Albuquerque, Oak Ridge (OR), Oakland, Richland (RL), and Savannah River. During the past 4 years, these sites have completed 262 ROI projects (costing $\$ 18.8$ million), with claimed first-year savings of $\$ 88$ million and claimed life cycle savings exceeding $\$ 300$ million.

\subsection{OBJECTIVE AND APPROACH}

The objective of this task was to assess the site-led, DOE-Headquarters (HQ)-funded, P2 ROI program. This assessment had two major guidelines: (1) perform a statistical sampling of completed ROI projects to validate estimated project costs and benefits and determine how the cost savings are returned to the site, and (2) evaluate site-level program management procedures and methods implemented to administer the ROI program.

The approach chosen for this assessment was to review 16 randomly-selected EM-funded ROI projects at two Operations Offices, OR and RL. Although this assessment does not constitute a comprehensive analysis of the program, the number of projects reviewed allows for a deeper understanding of the value of $\mathrm{P} 2$ investments. The 16 projects ( 8 from OR and 8 from RL) are listed in Attachment 1.

The 16 projects selected for evaluation were chosen from a list of completed ROI projects provided by EM-77. We used statistical sampling procedures to select eight projects from each Operations Office from this list. According to site representatives, some projects on the list had not yet been implemented, and some projects were not funded from the HQ ROI program, while some ROI projects were not listed. For example, OR informed us that the list of projects did not include the DOE HQ ROI funded projects for which EM money was awarded in 1994-

1996. There were eight projects from the Oak Ridge Y-12 Plant that were funded through this program and there is a great deal of documentation for those projects from which an evaluation could have been supported. Therefore, the list from which the sample was drawn may not have been representative of the breadth of $\mathrm{P} 2$ projects funded by the ROI program. Based on a review of the randomly selected projects, P2 coordinators believe that a more representative project listing could have resulted in a sample of projects that would have shown higher savings and increased non-monetary benefits. Therefore, the project approach may have contributed to an underestimate of the positive results reported in Sect. 3.

Of the 16 randomly selected projects: 
- $\quad$ Twelve projects were completed and implemented as planned. Project interviews were conducted for 11 of these (no interview was conducted for ORNL Digital Conversion in Materials Analysis Labs - project 14 in Attachment 1 - because it was funded before more formal ROI project proposal and tracking procedures were adopted.)

- $\quad$ One project has been partially implemented. The ORNL Cyanide by MIDI Distillation Upgrade Project (project 1) purchased equipment that is now being used for other P2 applications because its intended use has been delayed by certification problems.

- $\quad$ One project was unsuccessful. Y-12 Source Reduction of Heavy Equipment Oils (project 5) expended funds to purchase equipment, but the technology failed in field application.

- $\quad$ Two projects are not yet implemented. These projects -- the ETTP Direct Injection Nebulizer (project 16) and the ORNL Better Orange Parts Washer Project (project 15) expended funds to purchase equipment but have not yet been implemented (although they are expected to be) because of technical difficulties and organizational changes, respectively.

This report focuses on the 13 completed projects for which we conducted interviews (projects 1-13 in Attachment 1).

To evaluate the projects, we conducted face-to-face interviews at both OR and RL with the P2 coordinators and the project engineers and managers. During these meetings, the projects were described, project implementation costs were reviewed, and cost savings (over time) were assessed (see Sect. 3.1). Other project benefits were also evaluated (as discussed in Sect. 3.2).

\section{P2 PROJECT EVALUATION METHOD}

A life cycle analysis was performed to understand the full costs and benefits of the 13 P2 projects. Life cycle analysis is a systematic and comprehensive process for identifying, assessing, and comparing alternatives and for selecting and documenting a preferred alternative. A life cycle analysis includes all of the impacts that result from a course of action over the entire period of time affected by the action. For this study, the 13 projects were evaluated on four financial criteria and four non-monetary criteria.

\subsection{FINANCIAL EVALUATION CRITERIA}

The financial evaluation criteria were implementation cost, life cycle savings, ROI (\%), and life cycle savings per dollar invested (\%). Each is defined below.

- Implementation cost - Costs incurred

Life cycle analysis - a systematic and comprehensive process for identifying, assessing, and comparing alternatives - was used to evaluate the full costs and benefits of the thirteen $P 2$ projects. Four financial criteria and four non-monetary criteria were used in the evaluation. to implement the $\mathrm{P} 2$ project, such as equipment and material purchases, and staff time.

- Life cycle savings - The total cost savings to the government over the life of the P2 project. The approach to making this criterion operational is to estimate all cash flows over the project life (regardless of which DOE program pays those costs) and discount future cash flows to produce a net present value. This is done for both the baseline (absent the $\mathrm{P} 2$ project) and the $\mathrm{P} 2$ project; the difference is the life cycle savings of the $\mathrm{P} 2$ project. A discount rate of $2.7 \%$ was used for this analysis, per Office of Management and Budget (OMB) Circular A-94. 
The following five categories were used to further analyze the life cycle savings. The savings in these categories sum to the life cycle savings of the project.

1. Project savings on external purchases-Savings associated with the purchase of goods and services from commercial suppliers. Included in this category are costs for chemicals, new tanks and drums, motor oil, and commercial waste disposal services.

2. Project labor savings-Savings associated with reducing the time needed for site staff to complete their tasks. Often new technologies and procedures will reduce the labor-time needed, thus allowing staff to work on other tasks.

3. Savings on on-site services - Savings associated with services supplied by other organizations at DOE sites to the project. These savings include waste disposal services, analytical services, and security services.

4. Delayed savings-A category used to capture reductions in future (not current) work scope. For example, the project may eliminate work scope that otherwise would have become part of an environmental cleanup activity.

5. No cost savings-This category is used for projects that have not been completed or have not produced cost savings.

- $\quad$ ROI (\%) - A formula established by DOE to measure return on investment. It places emphasis on first-year savings. An ROI of 181, for example, would be interpreted as "the project returns 1.8 times more in savings in the first year than the project implementation cost." P2 coordinators use the ROI to estimate the time to pay back the initial P2 investment.

- Life cycle savings per dollar invested (\%) - This criterion represents a second way to assess the financial merit of a project by calculating the life cycle savings per dollar invested in the project. Unlike the ROI criterion, this criterion encompasses all cost savings accrued over the lifetime of the project. A number such as 1427 would be interpreted as "the project returns 14.27 times more in savings over the lifetime of the project than the project implementation cost."

\subsection{NON-MONETARY EVALUATION CRITERIA}

In addition to financial measures, the projects were evaluated on the following non-monetary attributes: pollution/waste prevented, environmental impacts, public and worker health and safety, and programmatic impacts. Definitions for each criterion and explanations of how each is implemented follow.

- Pollution/waste prevented - Did the project reduce the amount of pollutants released into the environment? If so, by how much? The approach to implementing this criterion was to specify seven subcriteria. The first six refer to types of wastes [mixed, hazardous, low-level (LLW), transuranic, TSCA, and sanitary] that could have been released into the environment. A seventh category labeled "other" was included as a placeholder to include unique P2 consequences of alternatives, such as those that may be related to energy conservation. P2 projects were evaluated based on the quantity and type of waste they avoided. 
- Environmental impacts - A criterion used to capture all other potential impacts a P2 project may have upon the environment. These include direct impacts on the site environment (e.g., the project reduces tritium released into the groundwater at the site) as well as secondary effects (e.g., reducing the need to manufacture new materials or products). The approach to implementing this criterion was to specify five subcriteria. Specifically, an alternative was assessed as to its consequences upon greenhouse gas emissions, air quality, drinking-water quality, land use, and biodiversity. The evaluation of each P2 project was based on the improvement in environmental impacts relative to the status quo absent the P2 project.

- Public and Worker Health and Safety Impacts - A criterion used to capture the changes in risk to public and worker health and safety directly attributable to a P2 project. This encompasses the risk to the total exposed population from both radiological and nonradiological causes (e.g., chemical exposure, transportation accidents, and occupational accidents).

- $\quad$ Programmatic Impacts - A criterion to capture the relationships between a P2 project and institutional issues of importance to program managers. Included in this category are factors such as improved ability to meet regulatory commitments and carry out specified procedures, improved productivity of staff (e.g., through reduced regulatory compliance record-keeping and reduction in time needed to complete tasks), potential for replicability at other sites, and improved competitiveness or effectiveness of the program.

\section{LIFE CYCLE ANALYSIS}

\subsection{ANALYSIS OF COST SAVINGS}

Table 1 summarizes the cost information about each of 13 projects. Details on the cost analysis are provided in Attachment 2. As can be seen in Table 1, project life ranges from 0 to 20 years. Implementation cost ranges from $\$ 2,000$ to $\$ 233,000$, with an average of $\$ 46,600$ and a total expenditure of $\$ 606,000$. Life cycle savings ranged from 0 to $\$ 22.3 \mathrm{M}$, with an average of $\$ 2.3 \mathrm{M}$, and a combined life cycle savings of $\$ 30 \mathrm{M}$. Overall, these results indicate that P2 projects yield high returns: 50 times the initial investment was saved by these $13 \mathrm{P} 2$ projects.

P2 projects perform better than expected

Number of projects that estimated ROI

Average ROI from project proposal

Average actual ROI
As seen in the ROI columns of Table 1, the cost savings reported herein are, in most cases, greater than those initially estimated by the projects. For 8 of the 11 projects that estimated the ROI in the project proposal, the ROI as determined through our interviews exceeded the ROI in the project proposal. In some cases, the improvement was due to increased throughput (e.g.,analyzing more samples than anticipated) or finding additional uses for the new equipment. In other cases,

project managers had under-estimated the ROI by not including the total benefits of their actions, but only the benefits to their projects. The fact is that many project benefits accrue to other organizations or programs. For example, project managers in OR do not always include in their P2 project assessments the cost savings and other benefits of reducing generation and disposal of wastes because their projects are not always charged for waste disposal services. Likewise, the ETTP Substitution of Poly Tanks Project did not take credit for providing tanks to another project, an action that directly prevented the recipient 
project from incurring a cost. Materials accounting such as that conducted for this study — tracking the physical flow of materials into, through, and out of a facility - can improve savings analyses.

Most of the cost savings are realized as reductions in demand for on-site services such as waste management (see Fig. 1). Of the $\$ 30$ million savings, the preponderance- $\$ 27$ million $(90 \%)$ - is in on-site services, with $\$ 2.6$ million $(8.6 \%$ ) in labor and $\$ 419,000$ $(1.4 \%)$ in avoided purchases from commercial vendors. The delayed savings category - used to capture reductions in future (not current) work scope - is not shown in Table 1 because none of the 13 projects showed savings in this category.

Since on-site services comprise the majority of the cost savings, that category merits further scrutiny. Of the reductions in on-site services costs, almost all is avoided waste management costs. RL and OR cost estimates were used to estimate the avoided waste management costs. These waste management savings are not seen immediately, for two reasons.

- $\quad$ First, waste management organizations tend to have a backlog of work and are receiving wastes from many different projects, so their work level (and funding level) is not typically reduced if a project does not send the expected quantities in a given year. Reducing waste quantities will allow the facility to work off its backlog more quickly; direct cost savings may not be seen until that time.

- $\quad$ Second, waste management facility costs consist of both a fixed-cost element and a variable-cost element. If generators produce less waste than expected, the variable-cost component is reduced, but in the near-term the fixed costs are unchanged.

While some of these on-site services costs may be charged back to the generator organization, typically the large fixed costs associated with waste management facilities are paid by the Office of Waste Management (EM-30) and not charged to projects.

P2 projects are like preventive maintenance - DOE spends money now to avoid large expenditures in the future
However, possibly the greatest cost impact of avoided waste quantities is not in these near-term savings but rather occurs in the future, as the Department is spared from having to build new disposal cells, waste treatment facilities, and storage units. In a real sense, P2 projects are like preventive maintenance - DOE spends money now to avoid large expenditures in the future. The estimates of avoided waste management costs include

the avoided operating costs associated with waste management; they do not include all of the fixed costs associated with constructing these facilities. Consequently, the true benefit of P2 investments may be significantly larger than reported here, as the Department is spared the cost of building new waste management facilities in the future. 
Table 1. P2 project costs and savings

\begin{tabular}{|c|c|c|c|c|c|c|c|c|c|c|}
\hline \multirow[b]{2}{*}{ Project name } & \multirow[b]{2}{*}{$\begin{array}{l}\text { Project } \\
\text { life } \\
\text { (years) }\end{array}$} & \multirow[b]{2}{*}{$\begin{array}{c}\text { Implementation } \\
\text { cost } \\
(\$ 1000)\end{array}$} & \multirow[b]{2}{*}{$\begin{array}{l}\text { Life cycle } \\
\text { savings } \\
(\$ 1000)\end{array}$} & \multirow[b]{2}{*}{$\begin{array}{l}\text { Life cycle } \\
\text { savings per } \\
\$ \text { invested } \\
(\%)\end{array}$} & \multicolumn{4}{|c|}{ Life cycle savings } & \multicolumn{2}{|c|}{ ROI } \\
\hline & & & & & $\begin{array}{c}\text { Project } \\
\text { savings- } \\
\text { purchases } \\
(\$ 1000)\end{array}$ & $\begin{array}{c}\text { Project } \\
\text { savings- } \\
\text { labor } \\
(\$ 1000)\end{array}$ & $\begin{array}{l}\text { On-site } \\
\text { services } \\
\text { savings } \\
(\$ 1000)\end{array}$ & $\begin{array}{c}\text { No } \\
\text { cost } \\
\text { savings }\end{array}$ & $\begin{array}{l}\text { ROI- } \\
\text { project } \\
\text { proposal } \\
(\%)\end{array}$ & $\begin{array}{c}\text { ROI- } \\
\text { this } \\
\text { study }^{\mathrm{a}} \\
(\%)\end{array}$ \\
\hline $\begin{array}{l}\text { ORNL Cyanide by MIDI } \\
\text { Distillation Upgrade }\end{array}$ & 15 & 48.8 & 766 & 1,570 & -50.6 & 810 & 7.1 & & 154 & 174 \\
\hline ORNL Mercury Analyzer Upgrade & 15 & 22.5 & 349 & 1,550 & -21.4 & 342 & 28.2 & & 109 & 120 \\
\hline $\begin{array}{l}\text { ETTP Purchase Data Security } \\
\text { Degausser }\end{array}$ & 10 & 27.8 & 274 & 987 & 255 & 11.1 & 8.11 & & 52 & 108 \\
\hline $\begin{array}{l}\text { ETTP Substitution of Poly Tanks } \\
\text { for Drums to Collect Acids }\end{array}$ & 2 & 21.4 & 105 & 489 & -9.6 & 14.1 & 100 & & 155 & 279 \\
\hline $\begin{array}{l}\text { Y-12 Source Reduction of Heavy } \\
\text { Equipment Oils }\end{array}$ & 0 & 37.1 & $<0^{\mathrm{b}}$ & N/A & 0 & 0 & 0 & $\mathrm{X}$ & 281 & -100 \\
\hline $\begin{array}{l}\text { RL Basin Overflow Retention } \\
\text { Tank }\end{array}$ & 4 & 13.1 & 1,450 & 11,000 & 0 & 660 & 787 & & 1,590 & 2,760 \\
\hline $\begin{array}{l}\text { RL TWRS Evaporator } \\
\text { Modification }\end{array}$ & 11 & 233 & 22,300 & 9,600 & 0 & -253 & 22,600 & & 370 & 764 \\
\hline RL Mixed Waste Rain Curtain & 7 & 149 & 791 & 532 & -39.8 & 95.6 & 735 & & 1691 & 115 \\
\hline RL Isolate Diversion Box & 10 & 17.5 & 3,410 & 19,500 & 0 & 677 & 2,736 & & 1,356 & 2,100 \\
\hline PNNL Microconcentric Nebulizer & 10 & 2 & 3.0 & 150 & -2.0 & 0 & 5.0 & & $\mathrm{na}^{\mathrm{c}}$ & $18^{\mathrm{c}}$ \\
\hline $\begin{array}{l}\text { RL Eliminate Solid Waste Stream } \\
\text { with Treatment and Recycling }\end{array}$ & 20 & 5.6 & 296 & 5,290 & 88.6 & 195 & 12.5 & & 99 & 324 \\
\hline RL In-Line Solvent Recovery & 10 & 21.6 & 48.9 & 226 & -6.6 & 8.0 & 47.5 & & 276 & 75 \\
\hline $\begin{array}{l}\text { PNNL Metallography } \\
\text { Photochemical Reduction }\end{array}$ & 6 & 6.7 & 249 & 3,720 & 205 & 30.4 & 13.4 & & $\mathrm{na}^{\mathrm{c}}$ & $650^{c}$ \\
\hline TOTAL & - & 606 & 30,000 & - & 419 & 2,590 & 27,100 & - & - & - \\
\hline AVERAGE & 9.2 & 46.6 & 2,310 & 4,200 & 32.2 & 199 & 2,080 & - & 558 & 611 \\
\hline
\end{tabular}

${ }^{a}$ Calculations are presented in Attachment 2

${ }^{b}$ Not quantified.

${ }^{c}$ PNNL internally funded projects; not funded through the ROI program. Not included in ROI average. 
Table 1 also presents two additional financial metrics, the ROI and an analogous statistic based on life cycle savings (see Sect. 2 for definitions). The ROIs range from $18 \%$ to $2760 \%$. The life cycle savings per dollar invested ranges from $150 \%$ to $19,500 \%$. Note the large discrepancy between the life cycle savings per dollar invested and the ROI calculation. This is because the ROI calculation does not take into consideration project life, whereas the life cycle cost calculation does consider (discounted) savings over the total life of the project. The ROI is used to estimate the return in the first year and the time to pay back the initial investment. It does not provide the total return over the life of the project. Thus, the life cycle savings figure of merit provides a truer picture of the financial value of the project. To be sure, the life cycle cost, in itself, does not tell the entire story because it fails to incorporate difficult-toquantify costs and benefits. To address this, we assessed the non-monetary benefits of each project. This is discussed in the next section.

\subsection{ASSESSMENT OF NON-MONETARY BENEFITS}

Table 2 summarizes the waste avoidance of the 13 P2 projects, and Table 3 summarizes the assessment of the projects over the four nonmonetary evaluation criteria presented in Sect. 2. The projects prevent the disposal of a significant amount of waste. Several projects show positive environmental impacts, for example, reducing release of tritium into groundwater. Several projects show positive health and safety impacts, primarily by reducing exposure of staff to hazardous and radioactive materials and secondarily through safer technologies and procedures. In addition, several projects show positive programmatic impacts, for example making it possible to meet Tri-Party Agreement milestones.

Table 2. Reduced waste generation resulting from $13 \mathrm{P} 2$ projects

\begin{tabular}{|l|l|}
\hline Waste Stream & Waste Reduction \\
\hline Mixed Low Level & 260,000 gal/year \\
\hline Low Level & $460 \mathrm{cubic}$ feet/year \\
\hline Hazardous & $460 \mathrm{gal} /$ year \\
\hline Sanitary Classified & $20 \mathrm{cubic}$ feet/year \\
\hline Sanitary & $4,100 \mathrm{gal} /$ year \\
\hline
\end{tabular}

\subsection{SUMMARY OF LIFE CYCLE ANALYSIS}

The results of the life cycle analysis are summarized in Table 4. Table 4 depicts two financial criteria implementation cost and life cycle savings — and the four non-monetary criteria. The latter are represented graphically to provide a more visual and intuitive method for understanding the assessment results. A guide to the ratings is provided in Attachment 3. Except for the one failed project, the life cycle analysis indicates that not only did the remaining projects provide substantial financial returns, but also in every case provided positive non-monetary benefits as well. 
Table 3. Assessment of non-monetary benefits of $P 2$ projects

\begin{tabular}{|c|c|c|c|c|}
\hline Project name & $\begin{array}{l}\text { Pollution/waste } \\
\text { prevented }\end{array}$ & $\begin{array}{l}\text { Environmental } \\
\text { impacts }\end{array}$ & $\begin{array}{l}\text { Health and safety } \\
\text { impacts }\end{array}$ & Programmatic impacts \\
\hline $\begin{array}{l}\text { ORNL Cyanide } \\
\text { by MIDI } \\
\text { Distillation } \\
\text { Upgrade }\end{array}$ & $\begin{array}{l}90 \text { gal of hazardous } \\
\text { waste per year }\end{array}$ & No impact & $\begin{array}{l}\text { Less worker exposure; } \\
\text { automated process } \\
\text { reduces handling }\end{array}$ & $\begin{array}{l}\text { Analysis time cut in half; } \\
\text { currently being used for P2 } \\
\text { applications for phosphate } \\
\text { and ammonia, which were } \\
\text { outside the original scope of } \\
\text { the project }\end{array}$ \\
\hline $\begin{array}{l}\text { ORNL Mercury } \\
\text { Analyzer } \\
\text { Upgrade }\end{array}$ & $\begin{array}{l}624 \mathrm{~L} \text { liquid LLW } \\
\text { per year }\end{array}$ & No impact & $\begin{array}{l}\text { Less technician } \\
\text { exposure to radiation, } \\
\text { safer machine to service }\end{array}$ & $\begin{array}{l}\text { Analysis time cut in half, } \\
\text { throughput capability } \\
\text { increased, and instrument } \\
\text { sensitivity improved }\end{array}$ \\
\hline $\begin{array}{l}\text { ETTP Purchase } \\
\text { Data Security } \\
\text { Degausser }\end{array}$ & $\begin{array}{l}481 \mathrm{~kg} \text { classified } \\
\text { sanitary waste per } \\
\text { year }\end{array}$ & $\begin{array}{l}\text { Reduced emissions } \\
\text { from burnhouse; } \\
\text { reduced need to } \\
\text { manufacture storage } \\
\text { media }\end{array}$ & No impact & $\begin{array}{l}\text { Improves adherence to } \\
\text { security procedures }\end{array}$ \\
\hline $\begin{array}{l}\text { ETTP } \\
\text { Substitution of } \\
\text { Poly Tanks for } \\
\text { Drums to } \\
\text { Collect Acids }\end{array}$ & $\begin{array}{l}2630 \mathrm{~kg} \text { solid LLW } \\
\text { per year }\end{array}$ & No impact & $\begin{array}{l}\text { Less chance of } \\
\text { radiation exposure }\end{array}$ & $\begin{array}{l}\text { Less staff time needed for } \\
\text { sampling, management, and } \\
\text { staging. Tanks are being } \\
\text { reused by other programs. }\end{array}$ \\
\hline $\begin{array}{l}\text { Y-12 Source } \\
\text { Reduction of } \\
\text { Heavy } \\
\text { Equipment Oils }\end{array}$ & $\begin{array}{l}\text { No benefit: Created } \\
\text { additional leaking oil }\end{array}$ & $\begin{array}{l}\text { No benefit: Created } \\
\text { additional leaking oil }\end{array}$ & $\begin{array}{l}\text { No benefit: Created } \\
\text { additional leaking oil }\end{array}$ & $\begin{array}{l}\text { Project led to used oil } \\
\text { recycling program that is } \\
\text { currently recycling } 100 \% \text { of } \\
\text { the oil }\end{array}$ \\
\hline $\begin{array}{l}\text { RL Basin } \\
\text { Overflow } \\
\text { Retention Tank }\end{array}$ & $\begin{array}{l}1200 \text { gal LLW per } \\
\text { year } \\
24 \text { drums LLW per } \\
\text { year }\end{array}$ & No impact & $\begin{array}{l}\text { Less worker exposure } \\
\text { to LLW and } \\
\text { occupational hazards }\end{array}$ & $\begin{array}{l}\text { Made it possible to meet Tri- } \\
\text { Party Agreement milestone }\end{array}$ \\
\hline $\begin{array}{l}\text { RL TWRS } \\
\text { Evaporator } \\
\text { Modification }\end{array}$ & $\begin{array}{l}370 \mathrm{~m}^{3} \text { liquid mixed } \\
\text { LLW per year }\end{array}$ & $\begin{array}{l}\text { Reduced river water } \\
\text { use, } \\
\text { reduced fish kill, } \\
\text { reduced chemical } \\
\text { use, and reduced } \\
\text { release of Tritium }\end{array}$ & $\begin{array}{l}\text { Less worker radiation; } \\
\text { less chemical exposure }\end{array}$ & $\begin{array}{l}\text { Made it possible to meet Tri- } \\
\text { Party Agreement milestone }\end{array}$ \\
\hline $\begin{array}{l}\text { RL Mixed } \\
\text { Waste Rain } \\
\text { Curtain }\end{array}$ & $\begin{array}{l}160,000 \text { gal leachate } \\
\text { per year for } 5 \text { years } \\
(\text { mixed LLW) }\end{array}$ & $\begin{array}{l}\text { Prevent failure of } \\
\text { trench }\end{array}$ & $\begin{array}{l}\text { Less radiological and } \\
\text { chemical exposure }\end{array}$ & $\begin{array}{l}\text { Extended life of trench; } \\
\text { prevented occurrences and } \\
\text { associated costs }\end{array}$ \\
\hline $\begin{array}{l}\text { RL Isolate } \\
\text { Diversion Box }\end{array}$ & $\begin{array}{l}3000-5000 \text { gal } \\
\text { process waste water } \\
\text { per year } \\
(\text { mixed LLW) }\end{array}$ & No impact & Less worker exposure & $\begin{array}{l}\text { Strengthened regulator } \\
\text { support }\end{array}$ \\
\hline $\begin{array}{l}\text { PNNL } \\
\text { Microconcentric } \\
\text { Nebulizer }\end{array}$ & 50 L LLW per year & $\begin{array}{l}\text { Less need for } \\
\text { chemicals }\end{array}$ & Less worker exposure & No impact \\
\hline
\end{tabular}


Table 3 (continued)

\begin{tabular}{|l|l|l|l|l|}
\hline Project name & \multicolumn{1}{|c|}{$\begin{array}{c}\text { Pollution/waste } \\
\text { prevented }\end{array}$} & \multicolumn{1}{|c|}{$\begin{array}{c}\text { Environmental } \\
\text { impacts }\end{array}$} & \multicolumn{1}{c|}{$\begin{array}{c}\text { Health and safety } \\
\text { impacts }\end{array}$} & Programmatic impacts \\
\hline $\begin{array}{l}\text { RL Eliminate } \\
\text { Solid Waste } \\
\begin{array}{l}\text { Stream with } \\
\text { Treatment and } \\
\text { Recycling }\end{array}\end{array}$ & $\begin{array}{l}\text { 4,100 gal sanitary } \\
\text { waste plus } 300 \text { gal } \\
\text { hazardous waste per } \\
\text { year }\end{array}$ & $\begin{array}{l}\text { Less need for new oil } \\
\text { and absorbent }\end{array}$ & Less worker exposure & $\begin{array}{l}\text { Strengthened regulator } \\
\text { support }\end{array}$ \\
\hline $\begin{array}{l}\text { RL In-Line } \\
\text { Solvent } \\
\text { Recovery }\end{array}$ & $\begin{array}{l}48 \text { kg hazardous } \\
\text { waste per year }\end{array}$ & $\begin{array}{l}\text { Less need for new } \\
\text { solvent }\end{array}$ & Less worker exposure & $\begin{array}{l}\text { Reduced sample preparation } \\
\text { time }\end{array}$ \\
\hline $\begin{array}{l}\text { PNNL } \\
\text { Metallography } \\
\text { Photochemical } \\
\text { Reduction }\end{array}$ & waste per year & Reduced chemical \\
need & Reduced chemical & exposure & $\begin{array}{l}\text { Improved productivity; } \\
\text { improved information } \\
\text { sharing }\end{array}$ \\
\hline
\end{tabular}


Table 4. Life cycle analysis reveals that $\mathrm{P} 2$ projects produce significant

financial and non-monetary rewards

\begin{tabular}{|c|c|c|c|c|c|c|}
\hline Project Name & $\begin{array}{c}\text { Implementation } \\
\text { Cost } \\
\text { (\$1000s) }\end{array}$ & $\begin{array}{l}\text { Life Cycle } \\
\text { Savings } \\
\text { (\$1000s) }\end{array}$ & $\begin{array}{l}\text { Pollution/ } \\
\text { Waste } \\
\text { Prevented }\end{array}$ & $\begin{array}{l}\text { Environmental } \\
\text { Impacts }\end{array}$ & $\begin{array}{l}\text { Health } \\
\text { and } \\
\text { Safety }\end{array}$ & $\begin{array}{l}\text { Programmatic } \\
\text { Impacts }\end{array}$ \\
\hline $\begin{array}{l}\text { ORNL Cyanide by MIDI } \\
\text { Distillation Upgrade }\end{array}$ & 49 & 766 & & & & \\
\hline $\begin{array}{l}\text { ORNL Mercury Analyzer } \\
\text { Upgrade }\end{array}$ & 23 & 349 & & & & \\
\hline $\begin{array}{l}\text { ETTP Purchase Data } \\
\text { Security Degausser }\end{array}$ & 28 & 274 & & & & \\
\hline $\begin{array}{l}\text { ETTP Substitution of Poly Tanks } \\
\text { for Drums to Collect Acids }\end{array}$ & 21 & 105 & & & & \\
\hline $\begin{array}{l}\text { Y-12 Source Reduction of } \\
\text { Heavy Equipment Oils }\end{array}$ & 37 & $<0^{a}$ & & & & \\
\hline RL Basin Overflow Retention Tank & 13 & 1,450 & & & & \\
\hline $\begin{array}{l}\text { RL TWRS Evaporator } \\
\text { Modification }\end{array}$ & 233 & 22,300 & & & & \\
\hline RL Mixed Waste Rain Curtain & 149 & 791 & & & & \\
\hline $\mathrm{RL}$ Isolate Diversion Box & 18 & 3,410 & & & & \\
\hline $\begin{array}{l}\text { PNNL Microconcentric } \\
\text { Nebulizer }\end{array}$ & 2 & 3.0 & & & & \\
\hline $\begin{array}{l}\text { RL Eliminate Solid Waste Stream } \\
\text { with Treatment and Recycling }\end{array}$ & 5.6 & 296 & & & & \\
\hline RL In-Line Solvent Recovery & 22 & 49 & & & & \\
\hline $\begin{array}{l}\text { PNNL Metallography Photochemic } \\
\text { Reduction }\end{array}$ & ical & 249 & & & & \\
\hline \multicolumn{3}{|c|}{$\begin{array}{l}\text { Major improvement relative to baseline approach } \\
\text { Some improvement }\end{array}$} & \multicolumn{4}{|c|}{ No change relative to baseline approach } \\
\hline
\end{tabular}

a Not quantified 


\section{ASSESSMENT OF MANAGEMENT PROCESS}

Both the Oak Ridge and the Richland Operations Offices have developed successful grassroots programs using streamlined processes which could serve as examples for the DOE complex. Dedicated teams administer the effort, champion the program, and assist generators in identifying P2 opportunities. Figure 2 provides a simplified view of Richland's ROI management process.

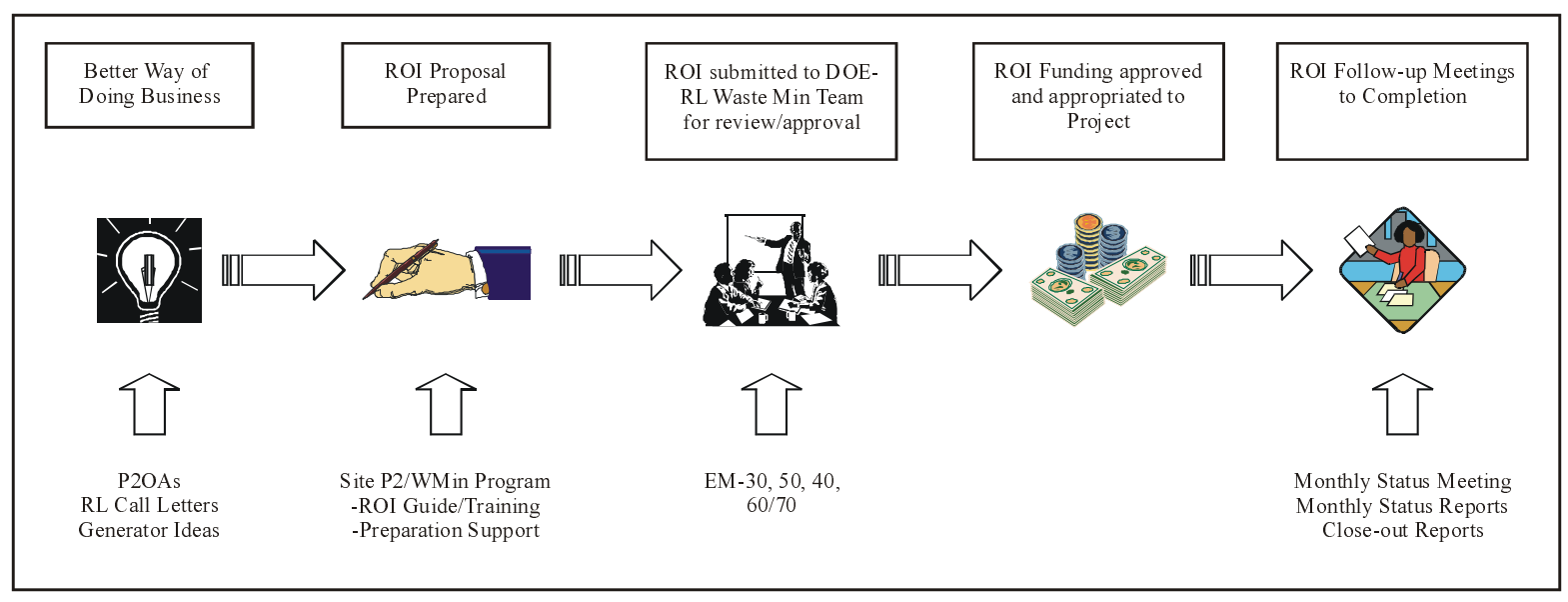

Fig. 2. Richland's ROI management process.

The P2 program has identified several elements of a successful DOE P2 ROI program. Some of the key elements are summarized in Fig. 3.

Fig. 3. Success factors for a successful DOE pollution prevention ROI program.

- Manage the program at the grassroots level in the field. Operate the program as an employee suggestion program.

- $\quad$ Set aside a separate source of funds from which the winning proposals are funded.

- Minimize paperwork burden. Provide simple proposal preparation guidelines and assist employees in preparing proposals. Provide tables that summarize site costs for waste, utilities, labor, materials, etc., to assist in determining life cycle savings.

- Integrate P2 education into the existing work structure (e.g., integrate with the ALARA program, NEPA program, energy efficiency program, training program, chemical management system, etc.)

- Identify a project champion — an essential ingredient in project success.

- $\quad$ Recognize employees for their efforts.

- $\quad$ Establish a simple, streamlined tracking system to monitor project progress and provide closure by confirming the savings. 
Key management issues that were identified include the following:

- $\quad$ Project managers do not see all the benefits of P2 opportunities; the ROI program looks past organizational "stovepipes" to fund projects that are cost-effective from the standpoint of DOE and taxpayers. Often costs and benefits cross organizational or project boundaries. For example, the OR projects reviewed do not pay for disposal of the waste they generate. Therefore, the implementing project would see the cost of waste-reducing activities, but not the benefits. As a result, projects sometimes do not have sufficient incentive and/or access to funding to implement P2 opportunities if the funding must come from their direct program budgets. The ROI program serves to bridge the gap whenever there are stovepipes that cause costs to accrue to one account and savings to be realized by another account. A common example of this is a generating organization realizing the cost of waste avoidance and a waste management organization realizing the savings.

- $\quad$ P2 staff stated the importance of having National Program funding that could not be taken for other site needs; without dedicated ROI funding, many of these projects would not be implemented. They stated two key reasons for this:

- $\quad$ Lack of regulatory or other drivers. Absent separate P2 funding, P2 projects must compete for funding with other site priorities. In this funding competition, "costeffectiveness" loses out to "compliance-driven" projects and other mission needs.

- $\quad$ Lack of management discretion. Project managers sometimes do not have management discretion to fund P2 projects within their project budget. In some cases, time constraints play a role. The project budget is fully committed for the year, and the manager has no discretionary funds. In other cases, the P2 projects require capital investments that projects sometimes cannot justify through routine maintenance and normal capital equipment requests.

- Non-monetary benefits of P2 projects, such as protection of natural resources, are typically not fully considered in decision-making. (In fact, the P2 ROI selection process is not structured to include questions related to benefits in the areas of health and safety, the environment, or programmatic impacts.) It is recommended that health and safety, environmental, and programmatic benefits be considered. In addition, it is recommended that, whenever possible, actual quantities of waste reduction be considered, rather than percentage reductions in current waste streams (as is done in OR). Attachment 3 provides an example of how these recommendations might be accomplished.

- We have two cautions on the use of the ROI formula developed by DOE:

- $\quad$ The ROI formula does not work well in all cases. Examples include projects with a one-time savings, projects in which annual operating costs vary from year to year, and projects for which the significant operating cost savings are delayed. For example, consider a project that makes it possible to avoid a large one-time capital expenditure, with no effect on operating cost. If the ROI formula is blindly applied, the ROI would be negative and the project would not be funded. It must be emphasized that neither OR nor RL blindly applies the ROI formula. Both sites have attained the sophistication to break from rigid criteria when the situation warrants. However, less sophisticated people do struggle with cases for which the ROI formula is not well suited, and all sites should be cautioned not to blindly apply the formula. 
- $\quad$ The ROI formula is used to estimate the first-year return and the time required to recover the initial investment. It does not provide information about the total return to the government over the total project life. Consider two projects: one with a life of 3 years, the second with a life of 30 years. Each requires an initial investment of $\$ 10,000$ and saves $\$ 20,000$ per year. The first project has an ROI of $167 \%$; the second has an ROI of $197 \%$, hardly different. Yet (neglecting discounting for this simple example) the first saves $\$ 50,000$ over the project life; the second project saves $\$ 590,000$, over half a million dollars more!

The life cycle savings figure of merit (reported in Table 1) is not susceptible to either of these problems and for this reason is recommended.

- A graded approach to project analysis and documentation is needed so that the time requirement is commensurate with the size and scope of the project. Excessive documentation can be a disincentive to participation in the ROI program. Both Oak Ridge and Richland have taken steps to streamline the process to reduce the administrative burden.

- $\quad$ The ROI program is changing the mind-set of site personnel. In addition to the reported benefits, $\mathrm{P} 2$ projects have produced unreported spinoff benefits because site personnel have developed the habit of looking for P2 opportunities. During the project interviews, several project managers discussed additional P2 ideas that were implemented -- for instance, recycling acid used to clean glassware, changing analytical techniques to reduce waste and manpower requirements, and recycling used transformers. Individuals, having developed the habit of looking for P2 opportunities, were implementing such changes in other aspects of their work. These spinoff benefits were not being documented in the $\mathrm{P} 2$ reporting system because personnel "don't want to stop working to document it." Although an analysis of these spinoff benefits is beyond the scope of this study, they seem to be a real benefit of the program.

In addition, we have an observation: there is an intentional bias toward near-term savings in the project selection process and a bias against projects that show no savings until the outyears. For example, RL told us that the selection process is biased against funding studies that could pay off in the future as reduced environmental cleanup costs. They view that as a programmatic initiative that the program should fund itself.

\section{ACKNOWLEDGMENTS}

We wish to acknowledge the excellent cooperation provided by the following P2 coordinators: David Wasserman, ORNL; Sheila Poligone, Y-12; and Anna Beard and Donna Merry, Richland. 


\section{Attachment 1. The Sixteen P2 Projects Selected for Assessment}

The 16 randomly selected projects are listed in the table below. This report focuses on the first 13 projects listed, all of them completed projects for which we conducted interviews.

\begin{tabular}{|c|c|c|c|}
\hline & Site & Project & Status \\
\hline 1 & OR & ORNL Cyanide by MIDI Distillation Upgrade & $\begin{array}{l}\text { Full implementation awaiting Utah certification } \\
\text { approval; currently being used for P2 } \\
\text { applications for phosphate and ammonia, which } \\
\text { were outside the original scope of the project. }\end{array}$ \\
\hline 2 & OR & ORNL Mercury Analyzer Upgrade & Complete \\
\hline 3 & OR & $\begin{array}{l}\text { ETTP Purchase Data Security HD-2000 } \\
\text { Degausser }\end{array}$ & Complete \\
\hline 4 & OR & $\begin{array}{l}\text { ETTP Substitution of Poly Tanks for Drums } \\
\text { to Collect Acids }\end{array}$ & Complete \\
\hline 5 & OR & $\begin{array}{l}\text { Y-12 Source Reduction of Heavy Equipment } \\
\text { Oils }\end{array}$ & $\begin{array}{l}\text { Technology failed in field use. However, the } \\
\text { project led to discovery of a new way to recycle } \\
100 \% \text { of the oil. }\end{array}$ \\
\hline 6 & RL & Basin Overflow Retention Tank & Complete \\
\hline 7 & RL & $\begin{array}{l}\text { Tank Waste Remediation System 242-A } \\
\text { Evaporator Modification }\end{array}$ & Complete \\
\hline 8 & RL & Mixed Waste Rain Curtain & Complete \\
\hline 9 & RL & Isolate 151S Diversion Box & Complete \\
\hline 10 & RL & Microconcentric Nebulizer & Complete \\
\hline 11 & RL & $\begin{array}{l}\text { Eliminate Solid Waste Stream with Treatment } \\
\text { and Recycling }\end{array}$ & Complete \\
\hline 12 & RL & In-Line Solvent Recovery & Complete \\
\hline 13 & RL & Metallography Photochemical Reduction & Complete \\
\hline 14 & OR & $\begin{array}{l}\text { ORNL Digital Conversion in Materials } \\
\text { Analysis Labs }\end{array}$ & Complete; no project interview conducted \\
\hline 15 & OR & $\begin{array}{l}\text { ORNL Better Orange \& KeMac TL3 } \\
\text { Aqueous Parts Washer }\end{array}$ & Incomplete; equipment not installed \\
\hline 16 & OR & ETTP Direct Injection Nebulizer & Incomplete; scheduled for completion $12 / 99$ \\
\hline
\end{tabular}


Attachment 2. Life Cycle Cost Analysis of Projects 
EXCEL SPREADSHEETS START HERE; 12 SPREADSHEETS 


\section{Attachment 3. Guide to the Ratings}

This attachment discusses how to develop qualitative ratings for non-monetary evaluation criteria. In this project, all the ROI projects were assessed over four non-monetary evaluation criteria: pollution/waste prevented, environmental impacts, health and safety, and programmatic impacts. These criteria are defined in Sect. 2.2. Thirteen ROI projects were evaluated over these four criteria, as shown in Table 4. The following five category scale was used for the evaluation:

1. Major improvements relative to baseline approach

2. Some improvement

3. No change relative to baseline approach

4. Somewhat worse

5. Major decline relative to baseline approach

For example, the first project listed in Table 4 - ORNL Cyanide by MIDI Distillation Upgrade — was evaluated over each non-monetary criterion by judging which evaluation category best describes the results of the project. In this case, it was judged that this project offered "some improvement" with respect to pollution/waste prevention over the baseline case (i.e., had the project not been funded and completed). Additionally, it was judged that this project resulted in "no change relative to the baseline approach" with respect to environmental impacts, "some improvement" with respect to health and safety, and "major improvements relative to baseline approach" with respect to programmatic impacts.

How were these and the judgments about the other twelve projects made? Generally, two approaches can be used to assist in this process. One, it useful to specify criteria that would guide how to rate the projects. For example, a project that prevented X kg or more of low level waste from being generated could be judged to show "major improvements relative to baseline approach." A project that prevented between 0 and $\mathrm{X} \mathrm{kg}$ of low level waste from being generated could be judged to show "some improvement."

Two, it is also useful to specify examples of projects that would fall into each rating category. These examples could be hypothetical, generated prior to assessing actual projects. One could also start by identifying projects that seem to represent the range of ratings, rate those projects, and then compare the remaining projects to these exemplars. A small group of people could be given the task of developing the set of examples and arriving at a consensus among themselves about what ratings each project should receive over each non-monetary criterion.

The amount of time devoted to one or both of these approaches by staff needs to be commensurate with the overall scope of the evaluation effort. Only a minimal amount of time is needed to specify some general criteria with respect to approach one and to rate a few examples with respect to approach two. Once actual evaluation of the projects begins, there will be enhancements to both approaches as more is learned about all the projects.

This is how we conducted the evaluation of the thirteen projects over the four non-monetary criteria. We established some general specification criteria for three of the four non-monetary criteria: pollution/waste prevention, environmental impacts, and health and safety. With respect to the first criterion, prevention of mixed waste was given priority and prevention of more than a small amount of mixed waste was rated as "major improvements relative to baseline approach." Significant direct environmental impacts, such as reducing releases to groundwater, were given primary priority with respect to environmental impacts. 
Any project that resulted in the slightest improvement in health and safety was judged at least "some improvement." With respect to programmatic impacts, we identified a project that "made it possible to meet Tri-Party Agreement milestone" as the example for the "major improvements relative to baseline approach" rating. Projects that did not achieve similar impressive programmatic results but did achieve some results received the "some improvement" rating.

We worked as a team to generate the ratings and we reconsidered the ratings as appropriate. The ratings we arrived at have internal validity. This means that we feel confident that the ratings illustrated in Table 4 are defensible and that the differences in the ratings among projects over the four non-monetary criteria are justifiable. This also means that the particular approaches to the ratings developed for this project do not have external validity and should not be generalized to other projects. In other words, it may not be the case that a rating of "major improvements relative to baseline approach" for one of the projects listed in Table 4 would be equivalent to a similar rating for a different project being evaluated in another evaluation context. External validity is an achievable goal. However, it takes agreement among all parties who will be doing evaluations about what each rating means. 


\section{INTERNAL DISTRIBUTION}

1. M. I. Morris

2. R. E. Swaja

3. B. E. Tonn

4-38. K. L. Yuracko

39. Laboratory Records-RC

40. Central Research Library

41-42. Office of Scientific and Technical Information

\section{EXTERNAL DISTRIBUTION}

43. A. V. Beard, U.S. Department of Energy, Richland Operations Office, P.O. Box 550, MSIN S755, Richland, WA 99352

44. A. Gonzalez, U.S. Department of Energy, Oak Ridge Operations Office, EM-923, 55 Jefferson, Oak Ridge, TN 37830

45. J. K. Hancock, U.S. Department of Energy, EM-77, 20400 Century Boulevard, Germantown, MD 20874

46. J. Lum, U.S. Department of Energy, EM-77, 20400 Century Boulevard, Germantown, MD 20874

47. C. Manrod, Bechtel-Jacobs Co. LLC, Building K-1001, MS-7123, P.O. Box 4699, Oak Ridge, TN 3781

48. P. Segal, Waste Management Services of Hanford, 2440 Stevens Center Place, P.O. Box 700, Mail Stop - MSINH6-06, Richland, WA 99352 